\title{
Fragen zur Wiederholung und Vertiefung
}

1. Worin unterscheiden sich das echte und das unechte Factoring?

2. Kennzeichnen Sie die gewerbesteuerliche Behandlung beim echten und unechten Factoring.

3. Beschreiben Sie, wie das Factoring nach dem Kreditwesengesetz eingestuft wird!

4. Was versteht man unter Forfaitierung? 